\title{
Activity patterns and foraging behaviour of Audouin's gulls in the Ebro Delta, NW Mediterranean*
}

\author{
SANTI MAÑOSA ${ }^{1}$, DANIEL ORO ${ }^{1,2}$ and XAVIER RUIZ ${ }^{1}$ \\ ${ }^{1}$ Dept. Biologia Animal, Vertebrats, Universitat de Barcelona, Avinguda Diagonal 645, 08028 Barcelona, Spain. \\ E-mail: d.oro@uib.es \\ ${ }^{2}$ Institut Mediterrani d'Estudis Avançats IMEDEA (CSIC-UIB), Miquel Marques 21, 07190 Esporles, Mallorca, Spain.
}

\begin{abstract}
SUMMARY: Twenty Audouin's gulls, Larus audouinii, breeding in the Ebro Delta (NW Mediterranean) were radio-tracked in 1998 to study their foraging behaviour and activity patterns. Some detrimental effects of tagging on the breeding success of the birds were detected, especially when both members of the pair were tagged. The results were actually constrained by the low number of locations due to natural breeding failure and failure in tag emission, as well as the adverse effect of tagging. However, through a combination of aircraft surveys at sea and a fixed station for automatic tracking of the presence of the birds at the colony, novel individual-based information of home ranges and activity patterns was obtained. Trawler fishing activity seemed to influence both the foraging range and habitat use: while trawlers operated, gulls overlapped their fishing grounds with vessels, probably to scavenge on discards. Very few locations were obtained during a trawling moratorium period, although they were all recorded in coastal bays and terrestrial habitats. During the trawling activity period, gulls ranged over a minimum convex polygon area of $2900 \mathrm{~km}^{2}$. Gulls were tracked up to $40 \mathrm{~km}$ from the colony, but some individuals were observed beyond $150 \mathrm{~km}$ while still breeding. Arrivals and departures from the colony were in accordance with the trawling timetable. However, most birds also showed some nocturnal foraging activity, probably linked to active fishing of clupeoids (following diel migrations) or to the exploitation of purse-seine fishing activity. Foraging trips lasted on average 15 hours: males performed significantly shorter trips than females, which spent more time outside the colony. The proportion of nocturnal time involved in the foraging trips was the same for males and females, but whilst all males initiated their trips both during the day and at night, some females only initiated their trips during the day. Hatching success was found to be related to foraging effort by males. Gulls spent on average ca. 38\% of their time budget outside the nesting territory, representing the time devoted mainly to flying, foraging and other activities.
\end{abstract}

Key Words: radiotracking, trawler fisheries, activity patterns, seabird, foraging range

RESUMEN: Patrones de actividad y COMPortamiento de CAZa en la Gaviota de Audouin en el delta del Ebro, MEDITERRÁNEO OCCIDENTAL. - El comportamiento de forrajeo de la gaviota de Audouin Larus audouinii y sus patrones de actividad fueron estudiados en la colonia del delta del Ebro (Mediterráneo noroccidental) mediante el marcaje con radioemisores. Detectamos algunos efectos negativos en la fecundidad de los individuos marcados, especialmente cuando los dos miembros de la pareja portaban radio-emisores. De hecho, los resultados estuvieron limitados por el bajo número de localizaciones debido a los fallos de señal de muchos de los emisores, los fracasos reproductivos y los efectos adversos del marcaje. La actividad de la flota de arrastre pareció influir tanto sobre el área de forrajeo como sobre el uso del hábitat: mientras los arrastreros faenaron, las gaviotas solaparon su actividad trófica con los caladeros de los barcos, muy probablemente para explotar los descartes generados por la flota. Se obtuvieron muy pocas localizaciones durante el periodo de veda de arrastre, pero todas ellas se registraron en bahías costeras y en hábitats terrestres (como los arrozales). Durante el periodo en que los arrastraron faenaron, las gaviotas se movieron sobre un área (método del mínimo polígono convexo) de $2900 \mathrm{~km}^{2}$. Mediante el radioseguimiento, se localizaron gaviotas a $40 \mathrm{~km}$ de la colonia, pero algunos individuos fueron observados más allá de los $150 \mathrm{~km}$ mientras aún estaban reproduciendose. Las llegadas y salidas de la colonia se solaparon con el horario de los arrastreros. Sin embargo, la mayoría de los animales mostraron también actividad nocturna, probablemente relacionada con el forrajeo natural de pequeños pelágicos (siguiendo las migraciones verticales de estos peces) o la asociación con pesquerías de cerco. Los desplazamientos de forrajeo duraron en promedio 15 horas: los machos realizaron desplazamientos significativamente más cortos que las hembras, que pasaron más tiempo fuera de la colonia. La proporción de horas noc-

*Received September 29, 2003. Accepted May 4, 2004. 
turnas empleadas en el forrajeo no varió estadísticamente entre machos y hembras, pero mientras todos los machos iniciaron sus desplazamientos tanto de día como de noche, algunas hembras sólo partieron de la colonia durante las horas de luz. El éxito de eclosión estuvo relacionado con el esfuerzo de forrajeo de los machos. Las gaviotas emplearon el $38 \%$ de su tiempo fuera de la colonia dedicándose a volar, alimentarse y a otras actividades.

Palabras clave: radioseguimiento, pesca de arrastre, patrones de actividad, aves marinas, área de campeo.

\section{INTRODUCTION}

Audouin's gull, Larus audouinii, is an ecological outlier among the Laridae, especially with regard to its foraging ecology. This is one of the few species in the family that mostly shows nocturnal feeding activity. Some occasional observations of marked breeders more than $160 \mathrm{~km}$ from the colony suggest that its foraging range is very large for a gull and that it may exploit a more pelagic habitat than usual (Burger and Gochfeld, 1996; Oro, 1998a). Moreover, the species is a foraging specialist in feeding on shoals of clupeoids (mainly sardine Sardina pilchardus and anchovy Engraulis encrasicolus) at night, taking advantage of their diel vertical migration cycles. These prey can represent more than $85 \%$ of the biomass intake of Audouin's gulls (Oro et al., 1997; Pedrocchi et al., 2002). This very narrow foraging niche width and specialised diet is also very rare among gulls (which usually show a very generalist diet and opportunistic foraging behaviour) and was one of the main factors proposed to explain the reduced distribution of the species and its small total population size (de Juana and Varela, 1993). The species is actually one of the few endemic seabird species of the Mediterranean region and during the 1970s it was considered one of the most endangered seabirds in the world (Burger and Gochfeld, 1996). However, the effective protection of breeding sites has probably led to a dramatic population increase during the last decades, especially in the western Mediterranean, where $90 \%$ of gulls reproduce (Oro, 1998a). Cessation of human persecution was crucial (Mayol, 1986), but the increase of food availability and a shift in foraging behaviour were also identified as key factors for this population increase. Several studies on scavenging seabirds around fishing vessels in the western Mediterranean have shown that Audouin's gulls use discards extensively and very efficiently (e.g. Oro and Ruiz, 1997; Arcos and Oro, 2002). This exploitation has enhanced the breeding performance of gulls and influenced its foraging ecology (e.g. Oro, 1995a; Oro et al., 1996). Nevertheless, little is known about the foraging range and activity budget of individual Audouin's gulls and the influence of sex and breeding status on the individual foraging behaviour in relation to fisheries. Baccetti et al. (2000) found that two Audouin's gulls breeding in Sardinia (central Mediterranean) tracked with bird-borne data loggers foraged at night and daytime at distances of up to 70 $\mathrm{km}$ from the colony. In the Ebro Delta colony (western Mediterranean), indirect data from counts suggest that birds may also forage during the day and at night at even larger distances from the colony, although the breeding status and features of these gulls could not be assessed (Arcos and Oro, 1996; Abelló and Oro, 1998a).

Remote-sensing systems have been widely used to study the foraging behaviour of seabirds, due to their mobility and large feeding ranges. Radiotelemetry was one of the first systems used to track these movements, although it has been progressively replaced by other new systems owing to the difficulty in obtaining fixes offshore (e.g. Wilson et al., 2002). However, new technologies are still too heavy for small and medium sized seabirds such as terns (e.g. Becker et al., 1993) or some gulls, including Audouin's gulls. We applied the radio-telemetry technology in a study of breeding Audouin's gulls in the Ebro Delta to obtain novel data on the foraging ecology of this seabird with regard to its feeding range and activity patterns, and the influence of trawling activity on them.

\section{METHODS}

\section{Study area}

The study was conducted in spring 1998 at Punta de la Banya, in the southern part of the Ebro delta

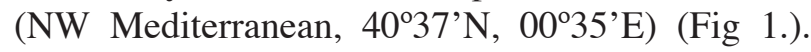
The area gave refuge to 11691 breeding pairs, the largest known Audouin's gull colony in the world (ca. $65 \%$ of the total population). The continental shelf off the delta extends $70 \mathrm{~km}$ offshore. This area is highly productive as a result of the Ebro river runoff and the influence of a shelf-slope front (Salat, 1996). Trawler fishing vessels operate in the Ebro 


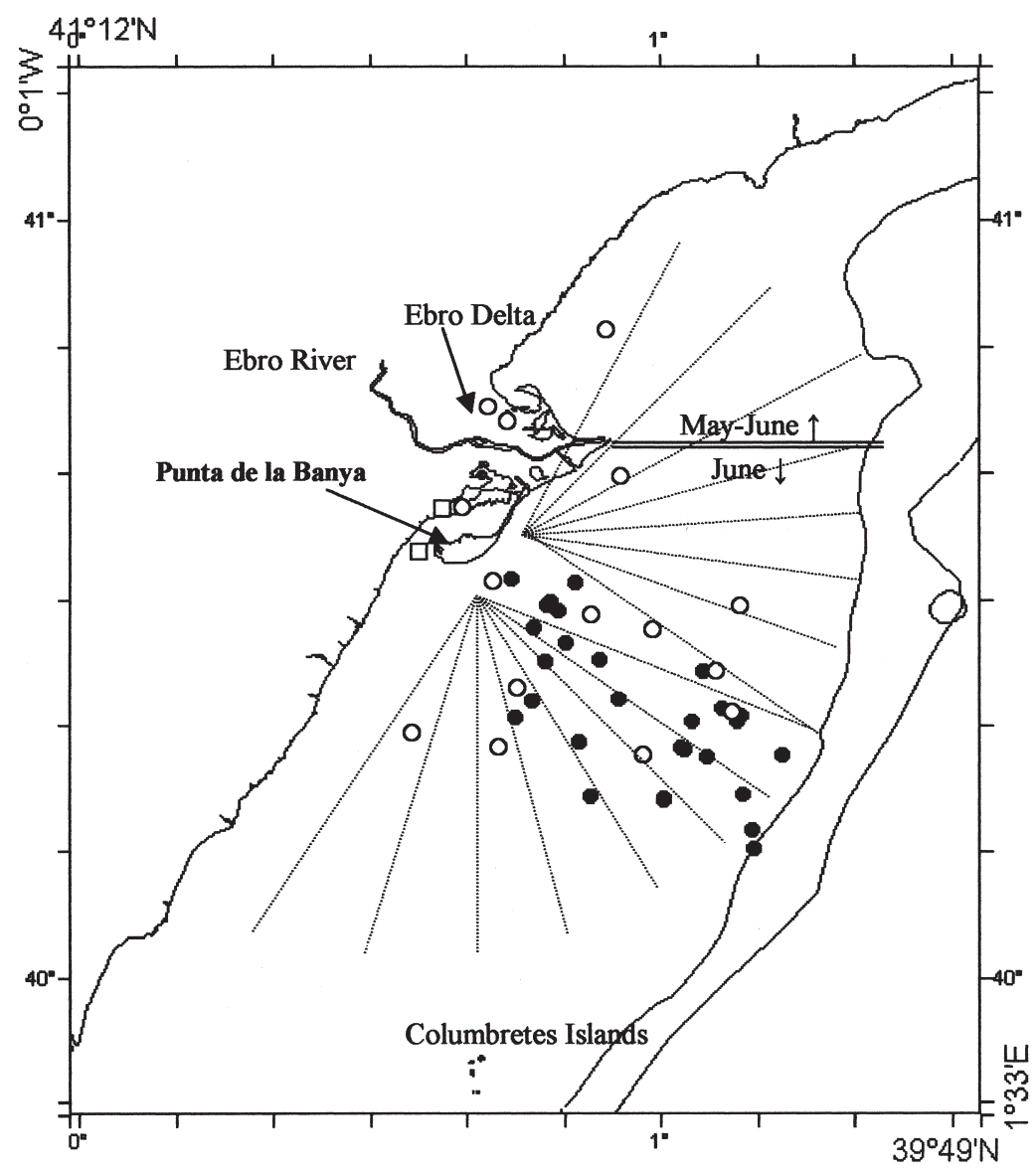

FIG. 1. - Map of the study area, the colony (Punta de la Banya) and the locations of radiotagged Audouin's gulls during aeroplane searching conducted between 18-26 May 1998 (open spots) and 8-12 June 1998 (open squares). Dashed lines indicate the pre-established flight path followed during each period. Solid spots show the location of trawling hauls performed by a sample of fishing vessels from St. Carles de la Ràpita and Vinarós, the two main fishing harbours operating in May during the study. These spots indicate the main area where trawlers were available in the non-moratorium area. The double line shows the areas and periods where moratorium was established. Above the line, no trawlers operated in May and June. Below, trawlers operated in May but not in June. The solid lines show the isobaths of $200 \mathrm{~m}$ and $1000 \mathrm{~m}$, i.e. the limits of the continental shelf.

delta area during the day from Monday to Friday. Purse seiners also operate in the area during the night, from Sunday night to Thursday night. A trawling moratorium has been established each spring on the Ebro delta continental shelf since 1991, overlapping every year with different breeding stages of the gulls (e.g. Oro et al., 1997). In 1998, during May and June, trawlers operated on the southern half of the continental shelf, but did not from the river mouth to $80 \mathrm{~km}$ further north. During June, trawling fishing was completely halted in the full area, from $80 \mathrm{~km}$ north to $115 \mathrm{~km}$ south of the river mouth (Fig. 1).

\section{Tagging}

Twenty gulls (10 males and 10 females) were trapped at the nests using falling cages on 5-7 May, during late incubation to reduce the risk of desertion
(Kania, 1992). They were fitted with $15 \mathrm{~g}$ TXH-2 Televilt (TVP Positioning AB, Bandygatan 2, SE71134 Lindesberg, Sweden) backpack transmitters with a $3 \mathrm{~g}$ silicon-tube harness. Total transmitter mass represented ca. $2 \%$ of adult body mass (average body mass of Audouin's gulls is ca. $620 \mathrm{~g}$, and males are on average 15\% larger than females (Oro, 1998a)). Eight complete pairs were captured plus two males and two females from another four pairs.

\section{Breeding success}

The breeding success of every tagged bird was established by enclosing the 12 nests of radio tagged gulls with a $1.5 \mathrm{~m}$ diameter and $0.2 \mathrm{~m}$ high $1 \mathrm{~cm}$ mesh metal fence that was bent inward at the top. This design prevented chicks younger than 30-35 days old from escaping without preventing adults from entering the enclosure, because we provided a 
resting ledge at the top of the fence where birds could land before entering the enclosure. The enclosures were built up $>2$ days after the birds had been caught, to avoid excessive simultaneous stress of tagging and fencing. Moreover, 48 control nests of non-tagged birds were also fenced to evaluate the effect of radio tagging on breeding success. Regular checks of the enclosures allowed us to count the number of chicks $<30-35$ days old at each nest.

\section{Aerial tracking}

A CESNA aircraft with a directional two-element yaggi antenna fixed on the right wing and an omnidirectional antenna on the left rear side of the plane was used to locate gulls at sea. Searching flights were carried out according to a pre-established flight pattern following 16 radial directions starting in the colony and going $58.5 \mathrm{~km}$ into the sea, up to the limits of the continental shelf. Each route was separated from the next by $15^{\circ}$ (Fig. 1). The full searching area was completely covered in four or five flight sessions of 4-5 hours from 11:00 to $15: 00 \mathrm{~h}$ conducted on consecutive days. The full area was covered in two separate periods. The first period, from 18 to 26 May, coincided with trawling fishing activity on the southern half of the Ebro Delta continental shelf, and a fishing moratorium established on the northern half; the second period, from 8 to 12 June, coincided with a complete halt of the trawling activity in the whole area. During the first period, $1110 \mathrm{~km}(82 \%)$ were flown over trawling areas and $235 \mathrm{~km}(18 \%)$ over non-trawling areas. During the second period, $1778 \mathrm{~km}$ were flown over the study area, and two more flights were also carried out following the coast to the north, up to $185 \mathrm{~km}$ from the colony, in order to locate birds that eventually foraged in areas beyond the trawling area around the Ebro Delta. Ranging areas were determined by the minimum convex polygon (MCP) (Kenward, 1987) encompassing all the fixes of foraging birds, including the colony. To assess the main area in which trawlers were available, the location of trawling hauls was recorded using GPS during 7 trips onboard trawlers from the two closest main fishing harbours operating during this study (J.M. Arcos, pers. com.).

\section{Automatic tracking and activity pattern}

A fixed Televilt RX-900 receiving station provided with a data-logger and powered by solar pan- els was installed at the centre of the colony. The receiver was set to sequentially scan the 20 frequencies, each for 60 seconds, twenty-four hours a day. The receiver was set so that only birds on land and within a $500 \mathrm{~m}$ radius from it were detected. Each time a given frequency was detected, the frequency, date and time of day (GMT) were recorded, in addition to the amplitude, period and intensity of the signal. Thus, for each bird it was possible to plot the strength of the signal received against time. The individual interpretation of these plots allowed the arrival and departure times of the birds in the colony to be established. The presence or absence from the colony of the tagged birds was recorded from Saturday 9 May 00:00 h (GMT) to Saturday 16 May 12:00 h (GMT), when all pairs were still incubating. Total automatic tracking time was $180 \mathrm{~h}$. During this period, sunrise time was 04:48 $\mathrm{h}$ and sunset time was 19:02 $\mathrm{h}$. These times were used as threshold values between daylight and nighttime.

\section{Statistical analysis}

For most analyses, non-parametric rank tests were used due to the nature of the data (count data not normally distributed) and the reduced sample size, which also determined the use of Fisher exact tests in contingency tables that show some cells with low observed frequencies.

\section{RESULTS}

Of the 20 tags, only 14 worked uninterruptedly during the tracking period, and their signal was received for periods ranging from 22 to 59 days (average $32 \pm 11$ days) before the birds were lost. Three transmitters failed abruptly within a period of 2-8 days after tagging, and three transmitted intermittently for periods of 5-29 days after tagging.

\section{Effect of tagging on breeding success}

Hatching success was similar in control pairs and in pairs in which only one member was tagged (Fisher exact test, $\mathrm{p}=0.85$ ), but a significant difference was found in the proportion of pairs hatching eggs between pairs with one or with two tagged birds (Fisher exact test, $\mathrm{p}=0.03$ ) (Table 1). Of the 12 breeding attempts involved in the study, only in 4 was the contact with the tagged bird lost before the breeding failure occurred. In the remaining 8 cases, 
TABLE 1. - Comparison of the breeding success (as number of fledglings per pair) between pairs with no tagged birds and those with one or two tagged birds.

\begin{tabular}{lccc}
\hline & One tagged & Two tagged & Not tagged \\
\hline n of pairs & 4 & 8 & 48 \\
n of pairs with hatchlings & $4(100 \%)$ & $2(25 \%)$ & $46(96 \%)$ \\
n of pairs with fledglings & $0(0 \%)$ & $0(0 \%)$ & $3(6.5 \%)$ \\
n of fledglings & 0 & 0 & 3 \\
Reproductive success & 0 & 0 & 0.06 \\
\hline
\end{tabular}

the tagged birds were detected alive after breeding failure. Among the 8 complete pairs that were tagged, only in 3 did the transmitters of both members of the pair work uninterruptedly during the continuous tracking period. Only in one of these pairs did we record the simultaneous absence from the colony of both male and female during this period. This pair left the nest unattended for periods of 2.16$5.6 \mathrm{~h}$ on five occasions during the continuous tracking period, and no chicks hatched. The other two pairs never left the nest unattended, and both hatched chicks.

\section{Home range and habitat use}

During the aircraft searches, we obtained 42 locations during the trawling activity period and 5 during the trawling moratorium period. Seven birds were never located (including three for which the tags were not working at all and three which worked only intermittently). For the remainder, we obtained 2-7 locations per bird (Fig. 2). During the first aircraft searching period, we obtained locations for 13 of the 14 birds for which the tags were working. During the second period, only 3 animals were located, all of which had also been located in the previous tracking week.

During the partial trawling activity period, gulls ranged over a minimum convex polygon (MPC) area of $2900 \mathrm{~km}^{2}$ area (Fig. 1). Foraging birds

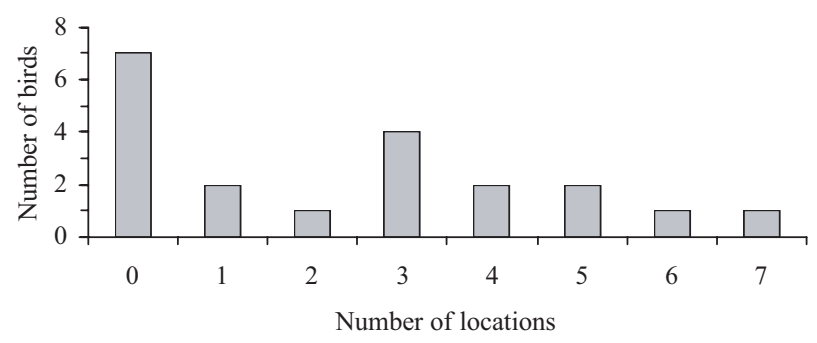

FIG. 2. - Frequency distribution of the number of locations by radiotagged birds.

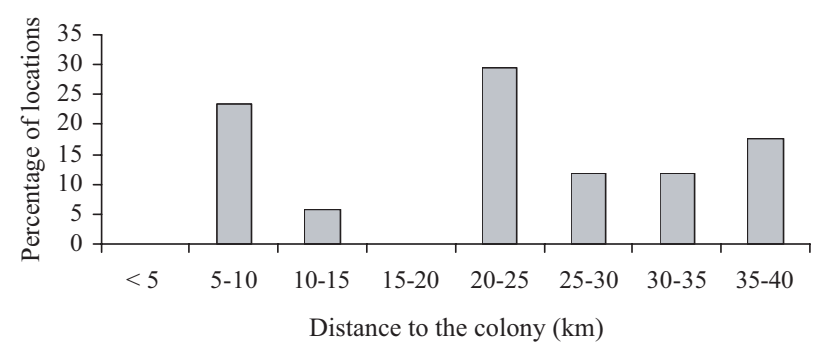

FIG. 3. - Frequency distribution of distances to the colony of the aeroplane locations of radiotagged gulls.

ranged between 5 and $40 \mathrm{~km}$ from the colony (Fig. 3 ), but may even have gone beyond, as the histogram does not show any declining trend on the right hand edge. During the fishing activity period, $27(57 \%)$ of the aircraft locations corresponded to birds in the colony and 15 (43\%) to foraging birds. Of these, only 1 involved a bird at sea within the moratorium area, 2 occurred on the delta rice fields, 1 on the Alfacs Bay, and 11 at sea within the fishing activity area. During aircraft searches conducted within the full fishing moratorium period, we obtained five locations, corresponding to three birds (of which only two still had chicks). Three were of birds in the colony and only two of birds looking for food, both in the delta area on terrestrial habitats, and none at sea (Fig. 1). During that week, however, only two birds were still breeding and carrying an active tag. The remaining 18 birds either carried a failed tag (6) or had already deserted (12). Considering both periods together, of the 17 aircraft locations of gulls outside the colony, 8 were found associated with trawlers, 4 at open sea not associated with trawlers, 2 on the delta bays, and 3 on rice fields (Table 2). For the 9 birds that were located from the aircraft on at least one occasion outside the colony, $89 \%$ were found at open sea, mostly in asso-

TABLE 2. - Habitat use of radiotagged Audouin's gull found outside the colony during aeroplane surveys between 18-26 May and 8-12 June 1998. The "Locations" column refers to the number of radiolocations corresponding to a given habitat. The total for this column corresponds to the total number of radiolocations $(n=17)$. The "Individuals" column refers to the number of tracked individuals $(n=9)$ that made use of a given habitat. Because one individual can make use of several habitats, the total for this column is larger than the number of individuals tracked.

\begin{tabular}{lcc}
\hline & $\begin{array}{c}\text { Locations } \\
(\mathrm{n}=17)\end{array}$ & $\begin{array}{c}\text { Individuals } \\
(\mathrm{n}=9)\end{array}$ \\
\hline Rice fields & $3(18 \%)$ & $3(33 \%)$ \\
Open sea & $12(70 \%)$ & $8(89 \%)$ \\
$\quad$ Associated with trawlers & $8(47 \%)$ & $7(78 \%)$ \\
$\quad$ Not associated with trawlers & $4(23 \%)$ & $4(44 \%)$ \\
Bays & $2(12 \%)$ & $1(11 \%)$ \\
\hline
\end{tabular}




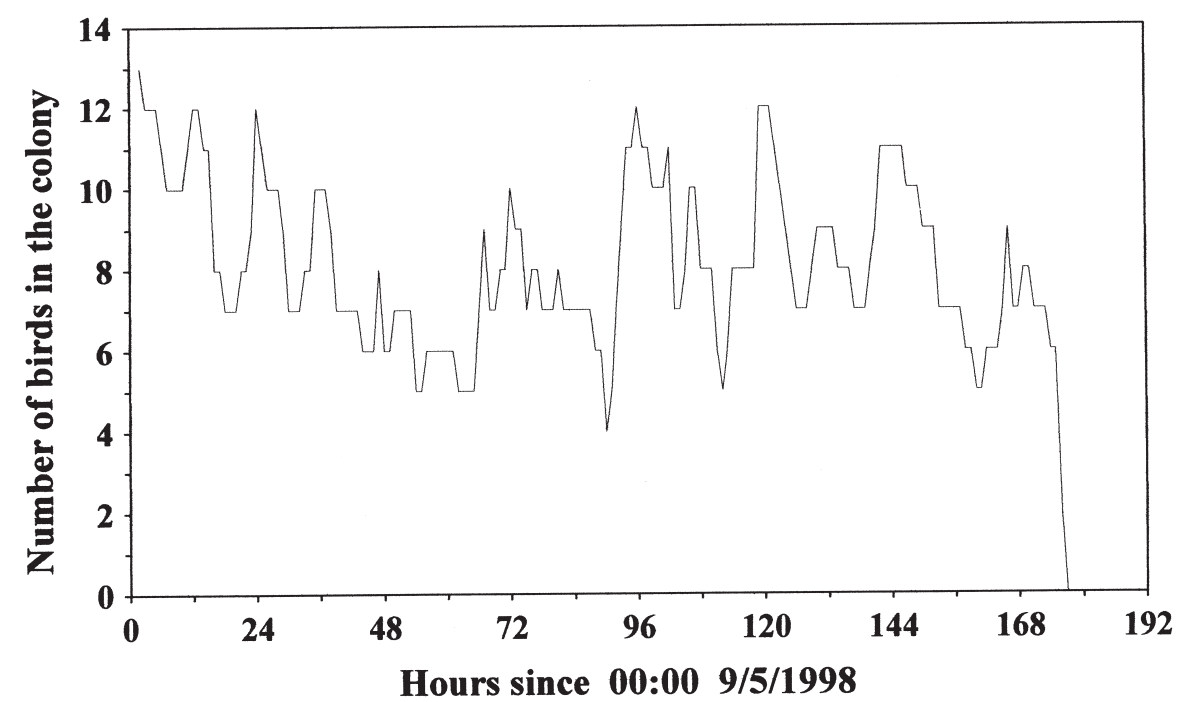

FIG. 4. - Progress of the number of tagged gulls present at the colony at one-hour intervals during a 7-day period. Only the 13 tags that were working during the full 7-day period are considered.

ciation with trawlers. The use of rice fields was proportionally more important than the use of bays, both in terms of locations and individuals involved (Table 2).

\section{Activity patterns: presence at the colony, depar- ture and arrival times}

The presence and movements of the gulls at and from the colony were tracked for 7.5 days from 9 to 16 May. The number of radio tagged gulls at the colony seems to follow a $24 \mathrm{~h}$ cycle, with a main peak at midnight, a minimum at dusk and a secondary peak around mid-day (Fig. 4). Male departures from the colony took place mainly after midnight (00:00-06:00 h) and in early afternoon (12:0014:00 h), whereas female departures took place mostly in early morning (04:00-08:00 h) and early afternoon (12:00-14:00 h) (Fig. 5). The individual percentage of nocturnal departures was significantly lower for females $(17 \%$, range: $0-50 \%, \mathrm{n}=7)$ than for males (47\%, range: $25-67 \%, \mathrm{n}=9)(\mathrm{U}$ MannWhitney, $\mathrm{z}=-2.358, \mathrm{p}=0.018)$. Individuals in our sample could be classed either as all-day-leavers (individuals that initiated foraging trips either at day or at night) or as exclusive daylight-leavers (birds that initiated foraging trips only in daylight). All males $(\mathrm{n}=9)$ behaved as all-day-leavers, whereas $57 \%$ of the females $(\mathrm{n}=7)$ were exclusive daylight leavers (Fisher exact test, $\mathrm{p}=0.019$ ). As a result, most nocturnal departures (79\%) were undertaken by males. Arrivals of both sexes took place mainly during the evening between 16:00 and 24:00 $\mathrm{h}$, though males also showed a peak of arrivals in the early morning (06:00-10:00 h), probably complementary of the early morning departure peak of females (Fig. 6). The individual percentage of nocturnal arrivals was significantly higher for females $(76 \%$, range: $33-$ $100 \%, \mathrm{n}=7$ ) than for males (45\%, range: $0-100 \%, \mathrm{n}$ = 9) $(\mathrm{U}$ Mann-Whitney, $\mathrm{z}=-1.980, \mathrm{p}=0.048)$. Among females, 3 were exclusive night-arrivers (returning to the colony exclusively at night).

\section{Frequency and duration of foraging trips}

During the tracking period (or total tracked time from all individuals together) (total observation time $=3192 \mathrm{~h}$. individuals) the tracked birds left the colony on 85 occasions. Each individual conducted

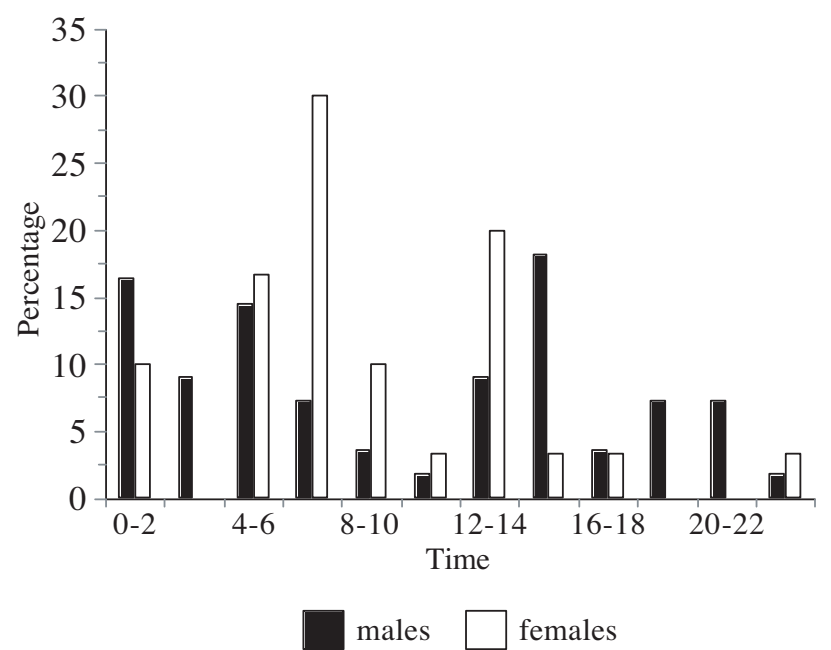

FIG . 5. - Departure times (GMT) for male $(n=55$ departure) and female $(n=30$ departures) radiotagged gulls. 


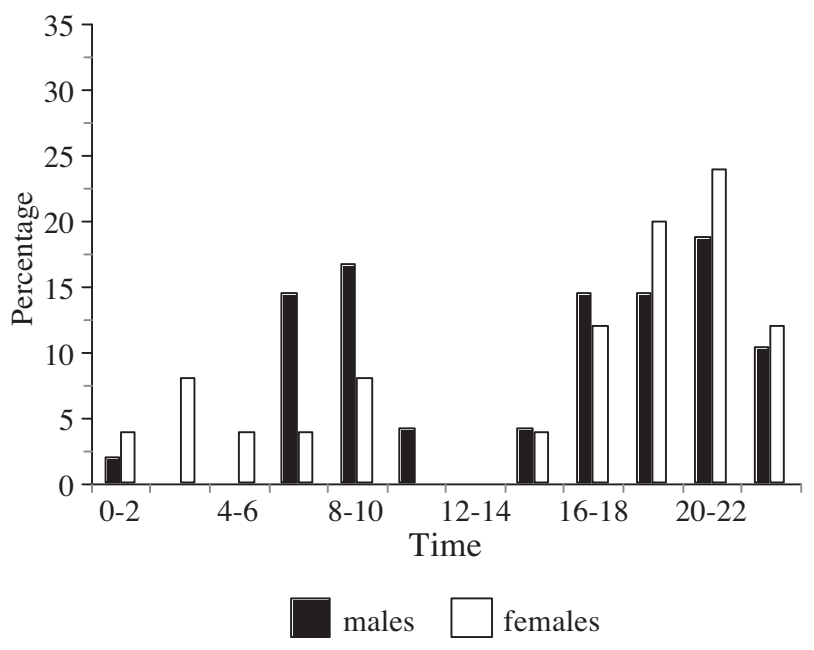

FIG . 6. - Arrival times for male $(\mathrm{n}=48$ arrivals $)$ and female $(\mathrm{n}=$ 25 arrivals) radiotagged gulls.

on average 0.62 trips/day (range: $0.34-1.00$ trips/day), or one trip every 38 hours (range: 24 - 71 h). The average time between the initiations of successive trips of the same individual was slightly longer for females $(1.60 \pm 0.95, \mathrm{n}=18$, range: 0.34 3.75 days $)$ than for males $(1.15 \pm 0.81, \mathrm{n}=38$, range: $0.29-3.40$ days $)(\mathrm{z}=-2.07, \mathrm{p}=0.038)$. The time at the colony between successive trips was $0.75 \pm 0.50$ days, $(\mathrm{n}=56$, range: 0.05-2.70 days), with no difference between genders or between pairs still raising chicks and those having already failed in reproduction. The mean $( \pm \mathrm{SD})$ length of foraging trips was $15.4 \pm 17.6 \mathrm{~h}(\mathrm{n}=72$, range: $1.3-78.3 \mathrm{~h})$, with a median of $8.2 \mathrm{~h}$. Male trips averaged $11.3 \pm 14.9 \mathrm{~h}$ ( $\mathrm{n}=47$, range: $1.3-78.3 \mathrm{~h}$ ), with a median of $5.6 \mathrm{~h}$, which was significantly shorter than for female trips $(23 \pm 20 \mathrm{~h}, \mathrm{n}=25$, range: $1.3-62.9 \mathrm{~h}$, median $=$ $12.9 \mathrm{~h})(\mathrm{z}=-3.22, \mathrm{p}=0.001)$. During foraging trips, one male was located in the Llobregat Delta, $>150$ $\mathrm{km}$ north of the colony. This male was again at the colony 15 days later, and had chicks on its nest until at least 18 days later.

\section{Individual activity budget}

On average, gulls spent $38 \pm 19 \%$ of their time outside the colony site $(n=16$, range: $10-76 \%$ ). Although non-significantly, females spent more time outside the colony $(46 \pm 24 \%, \mathrm{n}=7$, range: 10 $76 \%)$ than males $(33 \pm 11 \%, \mathrm{n}=9$, range: $14-47 \%)$ $(\mathrm{z}=-0,9 \mathrm{p}=0.368)$. Males at nests where eggs hatched successfully spent more time outside the colony (40 $\pm 9 \%, \mathrm{n}=4$, range: $29-48 \%)$ than males at nest where no chicks hatched $(27 \pm 12 \%, \mathrm{n}=5$, range: 14-46) (U Mann-Whitney, $\mathrm{z}=-1.960, \mathrm{p}=$
0.05). No such difference was found in females. The percentage of activity time corresponding to nighttime was $37 \pm 14 \%$ (range: $16-66 \%$ ), and showed no difference between males and females or between nests where chicks hatched and those where no chicks hatched. The duration of trips was significantly correlated to the total time outside the colony for males $\left(r_{s}=0.80, p=0.010\right)$ but not for females $\left(r_{s}=0.50, p=0.253\right)$. The number of trips conducted by the males was inversely correlated with the average duration of these trips $\left(r_{s}=-0.76, p=0.016\right)$ and directly correlated to the duration of female trips $\left(r_{s}=0.79, p=0.033\right)$. Compared with all-day-leaver females (females that initiated foraging trips both during the day and at night, $\mathrm{n}=3$ ), exclusive daylight leaver females (females that initiated foraging trips only during daylight, $n=4$ ) tended to conduct fewer (2.25 \pm 0.96 , range: $1-3$ vs. $5.33 \pm 1.53$; range: 4-7) but longer (32 $\pm 15 \mathrm{~h}$, range: $9.5-42.4$ vs. $20 \pm$ $13 \mathrm{~h}$, range: 10.0-34.2) trips, and their males tended to be more nocturnal $(47 \pm 13 \%$, range: $31-60 \%$ vs. $27 \pm 11 \%$, range: $16-38 \%$ of activity during the night). Although non-significantly, hatching success was higher among all-day-leaver females ( 2 out of 3 nests hatched) than among exclusive daylight leaver females ( 1 out of 4 nests hatched).

\section{DISCUSSION}

The interpretation of our results is constrained by low sample size. We failed to track many birds because of technological problems and, to a lesser extent, because of problems in the sampling protocol. Tagging may have had some effect on the breeding success of Audouin's gulls, especially when both members of a pair were tagged (Amlaner et al., 1978; Kania, 1992; Colwell et al., 1998). Similar remote systems applied to close related species, such as herring gulls Larus argentatus, also showed some detrimental effects (McCleery and Sibly, 1986), most probably linked to harnessing (Massey et al., 1988). In one case we found a flightless bird with the harness blocking the movement of a wing. Some observations such as birds spending time preening and trying to remove devices were also made, but their effects on foraging behaviour normal patterns could not be evaluated. However, in 1998 food availability was extremely low, as suggested by many indicators, some of them independent of our study on telemetry (Genovart et al., 2003). This severely affected the breeding success at 
the colony, causing premature migration and precluding a more prolonged and powerful analysis of activity and foraging patterns in different conditions.

Fencing could also have been an additional source of disturbance when carried out just after the catching of one or two adults. Our enclosure method is the best compromise between time devoted to setting up the fence and disturbance to birds. We have tested the effects of fencing on reproductive success since we set up fences since 1992. In 1998, we estimated breeding success also by using other simultaneous approaches (capture-recapture, fencing enclosing a group of nests, direct observations from a hide) and all of them showed a very low breeding success (Oro, 1998b), which was more probably associated with the bad environmental conditions that year.

The results suggest that trawling can affect several features of the foraging ecology of gulls breeding in the Ebro Delta. During the trawling period, the activity of the gulls at sea was concentrated in the area where trawlers were operating (Fig. 1). As a result, the foraging ranges were probably smaller here than in other colonies (Burger and Gochfeld, 1996; Oro, 1998a, Baccetti et al., 2000). Maximum foraging activity (as number of birds outside the colony) took place every day in mid-morning and mid-afternoon, whereas minimum activity occurred at midnight, suggesting that gulls may adjust their timetable to that of trawlers (Castilla and Jiménez, 1995; Oro, 1995a; González-Solís et al., 1999; Abelló et al., 2003), but also to that of purse-seiners or diel (vertical) migrations of cupleids (with one peak at dawn and another at dusk), which would explain why some birds leave the colony at or just before dawn, or arrive just before midnight. In the study area, Audouin's gulls probably exhibited a more marked pattern of diurnal activity than in other areas where fishing activity is not relevant for gulls (Gonzalez-Solis et al., 1999). Many seabird species obtain large amounts of food as discards from fishing vessels (e.g. Furness et al., 1992; Thompson and Riddy, 1995; Garthe et al., 1996; Walter and Becker, 1997), a foraging resource that is much easier to obtain than the food obtained through "natural" feeding techniques. In the western Mediterranean, this resource is also very predictable both in space and time, especially for trawlers, which always operate in the same fishing grounds off the harbours and in the same timetables (Martín, 1989; Oro, 1995a; Oro et al., 1997;
Martínez-Abraín et al., 2002). This factor probably enhances the learning of feeding locations, increasing foraging efficiency (see also Becker et al., 1993; Irons, 1998; Hamer et al., 2001; Hedd et al., 2001). Nevertheless, even when the main foraging resource was available (i.e. trawlers operating), some individuals still showed nocturnal activity linked to the feeding specialisation of the species, or to the exploitation of purse seine activity (Oro et al., 1997b; Arcos and Oro 2002).

Our study also confirms previous results based on counts and diet analysis (Arcos and Oro, 1996; Oro et al., 1997), indicating that during the trawling moratorium period, some individuals were located far from the colony, probably looking for discards in areas where trawlers still operated, at recorded distances of up to $150 \mathrm{~km}$. Audouin's gulls show larger foraging ranges (probably due to a higher ratio of wing surface relative to body mass) than terns and other gulls (e.g. Morris and Black, 1980; Fasola and Bogliani, 1990; Becker et al., 1993; Irons, 1998; Ostrand et al., 1998). When the main foraging resource (such as trawler discards) disappears or declines in a seabird community, the species with larger foraging ranges have higher buffering capacities for finding alternative food resources (e.g. Crawford and Shelton, 1981; Fasola et al., 1989; Oro, 1999). This is probably why Audouin's gulls show higher breeding performances than other gull species at the Ebro Delta colony when a trawling moratorium is established (see Oro, 1999, and references therein).

During the trawling moratorium, no tagged gulls were located foraging at open sea. Some other studies in the same area, however, have shown that gulls still forage at sea even when trawlers do not operate (Oro, 1995b; Abelló and Oro, 1998a; Abelló et al., 2003), probably taking advantage of the relatively high natural production of the continental shelf (Estrada, 1996), or in association with purse seiners (Arcos et al., 2001). Our results, then, are probably the consequence of birds leaving the colony after reproductive failure (Oro and Martínez-Vilalta, 1994), rather than a change in foraging behaviour associated with the trawling moratoria.

The length of foraging trips of Audouin's gulls in our study was three times higher ( $15 \mathrm{~h}$ on average) than that obtained by Oro et al. (1997) on the basis of nest watches, and also much higher than that recorded (using remote sensing systems) in other colonies (Baccetti et al., 2000) or in closely related species (Morris and Black., 1980; McCleery and 
Sibly., 1986; Anderson and Ricklefs, 1987 ; Becker et al., 1993; Garthe et al., 1999; Hamer et al., 2001). Even though most results in our study were recorded during incubation, when trips of seabirds are normally longer than during the chick rearing stage (Morris and Black, 1980; Hedd et al., 2001), longer foraging trips probably indicated a relatively low food availability that lasted up to the end of the breeding season (see also similar results in Morris and Black, 1980; Bukacinska et al., 1996). Breeding success in 1998 was actually the lowest since 1991 (Genovart et al., 2003), when the trawling moratorium was first established, and significantly lower than those recorded during the study of Oro et al. (1997) $\left(\chi^{2}=81.92, p<0.0001\right)$. However, more data on foraging ranges from different colonies and different years could show how this top predator utilises food resources.

Audouin's gulls in the Ebro delta showed sex differences in the activity pattern, unlike the observations for closely related species such as herring gulls (e.g. McCleery and Sibly, 1986; Bukacinska et al., 1996). Females of Audouin's gull conducted slightly less frequent, but much longer bouts than males. These differences could be related to sexual size dimorphism, which may influence different foraging patterns and habitats (e.g. González-Solís et al., 2000), but also to other sexual differences not related to body size (Lewis et al., 2002). They could also be the result (at least partially) of a higher detrimental harnessing effect on the smaller sex (i.e. females). Males also showed a stronger tendency to leave the colony during the night than females, some of which only started foraging trips during the day. Male foraging activity during incubation appears to be crucial in determining the incubation outcome. The fact that females that never initiate foraging trips at night tended to have lower hatching success than females that initiated foraging trips both during the day and at night, and that the former behaviour is associated with increased male nocturnality may indicate that this pattern of female activity may be caused by inadequate incubation switching during the night. Our results might also have consequences for conservation, since many adults are caught in long-line fisheries, especially at sunrise (Belda and Sánchez, 2001), and this might affect one sex more than the other. Different sex mortality has been recorded in some Procellariiformes species, with detrimental consequences on their population dynamics (e.g. Weimerskirch et al., 1997; Ryan and Boix-Hinzen, 1999; Nel et al., 2002).

\section{ACKNOWLEDGEMENTS}

We are grateful to A. Bertolero and the lighthouse keepers for their help in the building and maintenance of the receiving station. We also thank J.M. Arcos and M. Genovart for their help in the field work, and J.M. Arcos for his data on trawler locations. J.M. Arcos and two anonymous referees made very valuable comments which helped to improve the final manuscript. We are also grateful to P. Abelló for his comments and patience. The Departament d'Agricultura Ramaderia i Pesca of Generalitat de Catalunya provided the aircraft facilities and Joaquim, Ferran, Quim and Albert were tireless in trying to locate gulls at sea from the plain. Thanks are also due to A. Martínez-Vilalta, as a former biologist of the Ebro Delta Natural Park, for his continuous support and help. This research was funded by Project Life-Nature B4-3200/96/502. The manipulation of birds complied with the current local laws where the study was performed.

\section{REFERENCES}

Abelló, P. and D. Oro. - 1998. Offshore distribution and assemblages of breeding seabirds in the Catalano-Balearic Sea (northwestern Mediterranean). Col. Waterbirds, 21: 422-426.

Abelló, P., J.M. Arcos and L. Gil de Sola. - 2003. Geographical patterns of attendance to trawling by breeding seabirds along the Iberian Peninsula Mediterranean coasts. In: E. Mínguez, D. Oro, E. De Juana and A. Martínez-Abraín (eds.), Mediterranean seabirds and their conservation. Sci. Mar., 67(Suppl. 2): $69-75$

Amlaner, C.J., jr., R. Sibly and R. McCleery. - 1978. Effects of telemetry transmitter weight on breeding success in Herring Gulls. Biotelemetry 5: 154-163.

Anderson, D.J. and R.E. Ricklefs. - 1987. Radio-tracking Masked and Blue-footed Boobies (Sula spp.) in the Galápagos Islands. Nat. Geo. Res., 3: 152-163.

Arcos, J.M. and D. Oro. - 1996. Changes in foraging range of Audouin's Gull Larus audouinii in relation to a trawler moratorium in the western Mediterranean. Col. Waterbirds, 19: 128131.

Arcos, J.M. and D. Oro. - 2002. The role of nocturnal purse-seiners as a feeding resource for seabirds in the Ebro Delta area (NW Mediterranean). Mar. Biol., 141: 277-286.

Arcos, J.M., D. Oro and D. Sol. - 2001. Competition between the yellow legged gull Larus cachinnans and the Audouin's gull Larus audouinii associated with commercial fishing vessels: the influence of season and fishing fleet. Mar. Biol., 139: 807816.

Baccetti, N., L. Dall'Antonia, A. Magnani and L. Serra. - 2000. Foraging routes of Audouin's Gulls Larus audouinii from two Sardinian colonies. In: P. Yésou and J. Sultana (eds.), Monitoring and Conservation of Birds, Mammals and Sea Turtles of the Mediterranean and Black Seas, pp. 150-158. Environment Protection Department, Malta.

Becker, P.H., D. Frank and S.R. Sudmann. - 1993. Temporal and spatial pattern of common tern (Sterna hirundo) foraging in the Wadden Sea. Oecologia, 93: 389-393.

Belda, E.J. and A. Sánchez. - 2001. Seabird mortality on longline fisheries in the western Mediterranean: factors affecting bycatch and proposed mitigating measures. Biol. Cons., 98: 357-363. 
Bukacinska, M., D. Bukacinska and A.L. Spaans. - 1996. Attendance and diet in relation to breeding success in Herring Gulls (Larus argentatus). Auk, 113: 300-309.

Burger, J. and M. Gochfeld. - 1996. Family Laridae (Gulls). In: J. del Hoyo, A. Elliot and J. Sargatal (eds.), Handbook of the Birds of the World. Lynx Edicions, Barcelona.

Castilla, A. and J. Jiménez. - 1995. Relationships Between Fishery Activities and Presence of the Audouin's Gull (Larus audouinii) in the Columbretes Islands. Col. Waterbirds, 18: 108-112.

Colwell, M.A., C.L. Gratto, L.W. Oring and A.J. Fivizzani. - 1988. Effects of blood sampling on shorebirds: injuries, return rates and clutch desertions. Condor 90:942-945.

Crawford, R.J.M. and P.A. Shelton. - 1981. Population trends for some southern African seabirds related to fish availability. In: J. Cooper (ed.), Proceedings of the Symposium on birds of the sea and shore, pp. 15-41. African Seabird Group, Cape Town.

de Juana, E. and J.M. Varela. - 1993. La población mundial reproductora de la gaviota de Audouin (Larus audouinii ). In: J.S. Aguilar, X. Monbailliu and A.M. Paterson (eds.), Status and conservation of seabirds, pp. 71-85. SEO, Madrid.

Estrada, M. - 1996. Primary production in the northwestern Mediterranean. Sci. Mar., 60: 55-64.

Fasola, M. and G. Bogliani. - 1990. Foraging ranges of an assemblage of Mediterranean seabirds. Col. Waterbirds, 13: 72-74.

Fasola, M., G. Bogliani, N. Saino and L. Canova. - 1989. Foraging, feeding and time-activity niches of eight species of breeding seabirds in the coastal wetlands of the Adriatic Sea. Boll. Zool., 56: 61-72.

Furness, R.W. , K. Ensor and A.V. Hudson. - 1992. The use of fishery waste by gull populations around the British Isles. Ardea, 80: $105-113$

Garthe, S., C.J. Camphuysen and R.W. Furness. - 1996. Amounts of discards by commercial fisheries and their significance as food for seabirds in the North Sea. Mar. Ecol. Prog. Ser., 136: $1-11$

Garthe, S., D. Grémillet and R.W. Furness. - 1999. At-sea-activity and foraging efficiency in chick-rearing northern gannets Sula bassana: a case study in Shetland. Mar. Ecol. Prog. Ser., 185: 93-99.

Genovart, M., D. Oro, X. Ruiz, R. Griffiths, P. Monaghan and R.G. Nager. - 2003. Male-biased hatching sex ratio in Audouin's gulls. Condor, 105: 783-790.

González-Solís, J., J.P. Croxall and A.G. Wood. - 2000. Sexual dimorphism and sexual segregation in foraging strategies of northern giant petrels Macronectes halli, during incubation. Oikos, 90: 390-398

González-Solís, J., X. Ruiz and L. Jover. - 1999. Fisheries and daily activity cycles of Audouin's Larus audouinii and Yellowlegged Gulls L. cachinnans breeding at the Chafarinas Islands (Moroccan coast). Die Vogelwarte, 40: 52-56.

Hamer, K.C., R.A. Phillips, J.K. Hill, S. Wanless and A.G. Wood. - 2001. Contrasting foraging strategies of gannets Morus bassanus at two North Atlantic colonies: foraging trip duration and foraging area fidelity. Mar. Ecol. Prog. Ser., 224: 283-290.

Hedd, A., R. Gales and N. Brothers. - 2001. Foraging strategies of shy albatross Thalassarche cauta breeding at Albatross Island, Tasmania, Australia. Mar. Ecol. Prog. Ser., 224: 267-282.

Irons, D.B. - 1998. Foraging area fidelity of individual seabirds in relation to tidal cycles and flock feeding. Ecology, 79: 647-655.

Kania, W. - 1992. Safety of catching adult European birds at nest. Ringers' opinions. Ring 14: 5-50.

Kenward, R.E. - 1987. Wildlife radio tagging. Academic Press, London.

Lewis, S., S. Benvenuti, L. Dall'Antonia, R. Griffiths, L. Money, T.N. Sherratt, S. Wanless and K.C. Hamer. - 2002. Sex-specific foraging behaviour in a monomorphic seabird. Proc. Roy. Soc. London Ser. B, 269: 1687-1693.

Martín, P. - 1989. Dinámica de la pesquería de arrastre en Cataluña. $\mathrm{PhD}$ thesis, Universitat de Barcelona.

Martínez-Abraín, A., D. Oro and R. Maestre. - 2002. Demersal trawling waste as a food source for western Mediterranean seabirds during the summer. ICES J. Mar. Sci., 59: 529-537.

Massey, B.W., K. Keane and C. Boardman. - 1988. Adverse effects of radio transmitters on the behaviour of nesting least terns. Condor, 90: 945-947.
Mayol, J. - 1986. Human Impact on Seabirds in the Balearic Islands. In: Medmaravis and X. Monbaillu (eds.), Mediterranean Marine Avifauna: population studies and conservation, pp. 379-396. Springer-Verlag, Berlin.

McCleery, R.H. and R.M. Sibly. - 1986. Feeding specialization and preference in Herring Gulls. J. Anim. Ecol., 55: 245-259.

Morris, R.D. and J.E. Black. - 1980. Radiotelemetry and Herring Gull foraging patterns. J. Field Orn., 51: 110-118.

Nel, D.C., P.G. Ryan, J.L. Nel, N.T.W. Klages, R.P. Wilson, G. Robertson and G.N. Tuck. - 2002. Foraging interactions between Wandering Albatrosses Diomedea exulans breeding on Marion Island and long-line fisheries in the southern Indian Ocean. Ibis, 144: 141-154.

Oro, D. - 1995a. The influence of commercial fisheries in daily activity of Audouin's Gull Larus audouinii in the Ebro Delta, NE Spain. Ornis Fennica, 72: 154-158.

Oro, D. - 1995b. Audouin's gull associate with sub-surface predators in the Mediterranean sea. J. Orn., 136: 465-467.

Oro, D. - 1998a. Audouin's gull account. In: M.A. Ogilvie (ed.), The Birds of Western Paleartic, pp. 47-61. Oxford University Press, Oxford.

Oro, D. - 1998b. Censo de nidificantes, reproducción y anillamientos de gaviota de Audouin (Larus audouinii) en el delta del Ebro (campaña 1998). Report project LIFE B4-3200/96/502. Generalitat de Catalunya-Universitat de Barcelona.

Oro, D. - 1999. Trawler discards: a threat or a resource for opportunistic seabirds? In: N.J. Adams and R.H. Slotow (eds.), Proc 22 Int. Ornithol. Congr., pp. 717-730. Birdlife South Africa, Johannesburg.

Oro, D., L. Jover and X. Ruiz. - 1996. Influence of trawling activity on the breeding ecology of a threatened seabird, Audouin's gull Larus audouinii. Mar. Ecol. Prog. Ser., 139: 19-29.

Oro, D. and A. Martínez-Vilalta. - 1994. Migration and dispersal of Audouin's gull from the Ebro delta colony. Ostrich, 65: 225-230.

Oro, D. and X. Ruiz. - 1997. Seabirds and trawler fisheries in the northwestern Mediterranean: differences between the Ebro Delta and the Balearic Is. areas. ICES J. Mar. Sci., 54: 695-707.

Oro, D., X. Ruiz, L. Jover, V. Pedrocchi and J. González-Solís. 1997. Audouin's Gull diet and adult time budget responses on changes in food availability induced by commercial fisheries. Ibis, 139: 631-637.

Ostrand, W.D., G.S. Drew, R.M. Suryan and L.L. McDonald. 1998. Evaluation of radio-tracking and strip transect methods for determining foraging ranges of Black-legged Kittiwakes. Condor, 100: 709-718.

Pedrocchi, V., D. Oro, J. González-Solís, X. Ruiz and L. Jover. 2002. Differences in feeding ecology between the two largest breeding colonies of Audouin's gulls: the effects of fishery activities. Sci. Mar. 66: 313-320.

Ryan, P.G. and C. Boix-Hinzen. - 1999. Consistent male-biased seabird mortality in Patagonian toothfish longline fishery. Auk 116:851-854.

Salat, J. 1996. Review of hydrographic environmental factors that may influence anchovy habitats in northwestern Mediteranean. In: I. Palomera and P. Rubiés (eds.). The European anchovy and its environment. Sci. Mar., 60 (Suppl. 2): 21-32.

Thompson, K.R. and M.D. Riddy. - 1995. Utilization of offal and discards from "finfish" trawlers around the Falkland Islands by the Black-browed Albatross Diomedea melanophris. Ibis, 137: 198-206.

Walter, U. and P.H. Becker. - 1997. Occurrence and consumption of seabirds scavenging on shrimp trawler discards in the Wadden Sea. ICES J. Mar. Sci. 54: 684-694.

Weimerskirch, H., N. Brothers and P. Jouventin. - 1997. Population dynamics of wandering albatross Diomedea exulans and Amsterdam Albatross $D$. amsterdamensis in the Indian Ocean and their relationships with long-line fisheries: conservation implications. Biol. Cons., 79: 257-270.

Wilson, R.P., D. Grémillet, J. Syder, M.A.M. Kierspel, S. Garthe, H. Weimerskirch, C. Schäfer-Neth, J.A. Scolaro, C.-A. Bost, J. Plötz and D. Nel. - 2002. Remote-sensing systems and seabirds: their use, abuse and potential for measuring marine environmental variables. Mar. Ecol. Prog. Ser., 228: 241-261.

Scient. ed.: P. Abelló 